\title{
Penyuluhan Peran Santri Dalam Menjawab Tantangan Dakwah Di Era Digital
}

\author{
Septian Arief Budiman ${ }^{\text {a1 }}$, Fil Isnaeni ${ }^{\text {b2 }}$ \\ ${ }^{\mathrm{a}, \mathrm{b}}$ Fakultas Ekonomi, Universitas Pamulang* \\ 11dosen01126@unpam.ac.id; ${ }^{2}$ dosen01086@unpam.ac.id \\ *Korespondensi penulis
}

Naskah diterima: 22 Agustus 2019, direvisi: 15 September 2019, disetujui: 24 September 2019

\begin{abstract}
Abstrak
Era digital menjadikan pecahan baru strategi dakwah yang membuat para pelakunya untuk merubah arah dakwah yang sesuai dengan kebutuhan masyarakat, santri merupakan kader dakwah Islam yang sangat penting dan harus berperan aktif dalam mengembangkan dakwah Islam, pondok pesantren hidayatulmubtadiin dan nurulummahputri merupakan pencetak santri unggul dan inovatif diharapkan mampu mengikuti perkembangan dakwah di era digital, beriringan dengan hal tersebut dosen pendidikan agama Islam mempunyai tugas khusus untuk mengawal perkembangandakwahIslam melalui tridharma perguruan tinggi dilaksanakanlah kegiatan pengabdian kepada masyarakat di kedua pondok pesantren tersebut (Hidayatul Mubatadiin dan Nurul Ummah Putri), hasil dari kegiatan ini adalah terciptanya pemahaman model dan strategi dakwah bagi santri dan kesiapan santri dalam menghadapi tantangan dakwah di era digital setelah dilaksanakan diskusi interaktif dan kerjasama berupa MoU antara Universitas Pamulang dan Pondok Pesantren Hidayatul Mubatdi ien dan Nurul Ummah Putri dengan harapan dari MoU tersebut dapat menjalin ikatan dakwah Islam yang lebih kuat kedepannya.

Kata-kata kunci: Santri, Dakwah, Era Digital.
\end{abstract}

\begin{tabular}{l} 
Abstract \\
\hline The digital era made a new fraction of the da'wah strategy that made the perpetrators to \\
change the direction of da'wah in accordance with the needs of the community, the santri was \\
a very importantcadre of Islamic da'wah and had to play an active role in developing Islamic \\
da'wah and innovative is expected to beable to keep abreast of the development of da'wah in \\
the digital era. Alongwiththis, lecturers of Islamic religious education have a special duty to \\
oversee the development of Islamic indictment through the tridharma of tertiary institutions to \\
carryout community service activities in both Islamic boarding schools the result of this \\
activity was the creation of an understanding of the model and strategy of da'wah for santri \\
and the readiness of santri in facing the challenges of da'wah in the digital era after \\
interactive discussions and collaboration in the for mof a MoU between theUniversity of \\
Pamulang and Pondok Pesantren Hidayatul Mubatdi'ienand Nurul Ummah Putri hoped that \\
the MoU wouldestablish a stronger Islamic da'wah in the future.
\end{tabular}

Keywords: Santri; Dakwah; Digital Era 


\section{PENDAHULUAN}

Perkembangan teknologi senantiasa membawa inovasi manusia dalam menjalani kehidupan tidak terkecuali dakwah Islam, berbagai tantangan yang dihadapi di era digital juga tidak sedikit.

Era digital identik pada penggunaan gawai (Gadget) tentunya mempunyai dampak positif dan negatif, perubahan besar dunia disebab oleh semakin canggihnya teknologi pada masa kini. Akses informasi dapat dilakukan dengan mudah oleh manusia dengan banyak cara, serta dengan bebas dapat menikmati fasilitas dari teknologi digital, namun muncul pula dampak negatif dari teknologi digital sebagai ancaman.

Muncul tindak kejahatan yang difasilitasi oleh teknologi seperti game online yang dapat merusak mental generasi muda, pornografi, dan pelanggaran hak cipta yang dengan mudah dilakukan, dan lain-lain (Setiawan, 2017: 2).

Pesantren harus mampu menyiapkan sumber daya dan sumber dana untuk membangun fasilitas yang mencukupi kegiatan operasional pesantren, agar pesantren dapat berperan total menjadi sebuah lembaga pendidikan bagi masyarakat baik dari segi keilmuan agama maupun pendidikan formal (Maesaroh, 2017).
Upaya perluasan dan persebaran kesempatan bagi anak-anak untuk memperoleh pendidikan, khususnya pendidikan dasar menempati prioritas tertinggi dalam perkembangan pendidikan nasional.

Hal ini sangat beralasan, sebab Undang-Undang Dasar 1945 dan Garis-garis besar Haluan Negara telah mengamanatkan bahwa tiap-tiap warga negara berhak mendapat pendidikan dan pengajaran, pemerintah berupaya untuk memperluas kesempatan pendidikan, baik pendidikan dasar, kejuruan, professional, melalui jalur sekolah dan jalur luar sekolah.

Hal ini telah disadari oleh pengelola pondok pesantren Hidayatul Mubtadi ien dan Nurul Ummah Putri, letak geografis kedua pondok pesantren ini sangat strategis yaitu di daerah perkotaan yang membuat kedua pondok pesantren ini dapat dijadikan role model pondok pesantren berbasis IT dengan tidak meninggalkan kesan tradisionalnya.

Tugas dan fungsi pesantren di era modern mengalami perubahan. Peran pesantren di era modern sangat diharapkan sebagaimana dijelaskan dalam kaidah PP no.55/2007 dan PMA no.13/2014 tentang pesantren sebagai lembaga pendidikan keagamaan Islam yang memiliki sumber daya manusia yang dalam pengelolaannya, 
searah dengan perkembangan zaman dituntut untuk selalu dinamis dan berkemajuan dalam IPTEK sehingga pesantren juga berfungsi sebagai cagar budaya asli Indonesia dan budaya asing dalam peradaban dunia.

Pengaruh pesantren dan santri terhadap bangsa sangat berperan dalam kemerdekaan Bangsa Indonesia. Namun kelemahan pondok pesantren dalam pengelolaannya yang masih menggunakan tradisi, bukan profesionalisme berdasarkan keahlian (skill), baik human skill, conceptualskill, maupun technicalskillsecara terpadu. Akibatnya, tidak ada perencanaan yang matang, distribusi kekuasaan atau kewenangan yang baik dan sebagainya.

Tujuan diadakan kegiatan pengabdian kepada masyarakat ini adalah sebagai peran serta dosen dalam menjawab tantangan sosial yang terjadi di tengahtengah masyarakat dalam menghadapi perkembangan teknologi di era digital serta mengoptimalisasi teknologi sebagai sarana dakwah bagi subjek pengabdian yaitu santri pondok pesantren Hidayatul Mubatadiien dan Nurul Ummah Putri.

Pengabdian kepada masyarakat ini dilaksanakan dengan harapan terbentuknya para santri yang unggul dibidang teknologi dan memahami tantangan dakwah di era digital serta mampu menghadapi tantangan tersebut.

Dalam menuntaskan permasalahan diatas maka dosen agama Islam yang bernaung di prodi akuntansi S1 Universitas Pamulang mengadakan pengabdian kepada masyarakat berupa penyuluhan dan diskusi interaktif tentang menghadapi tantangan pembelajaran Pendidikan Agama Islam (PAI) dan dakwah Islam di era digital dengan para santri pondok pesantren Hidayatul Mubtadi ien dan Nurul Ummah.

\section{METODE}

Pengabdian kepada masyarakat ini bertempat di Pondok Pesantren Hidayatul Mubtadi`ien, Nurl Ummah dan Madrasah Aliyah Nurul Ummah yang berlokasi di Kotagede Yogyakarta, dilaksanakan pada Juli 2019.

Target atau subjek pengabaian kepada masyarakat ini ialah para santri dari dua pondok pesantren Hidayatul Mubtadi ien dan Nurul Ummah yang secara bersamaan mereka bersekolah di Madrasah Aliyah Nurul Ummah.

Metode yang digunakan pada kegiatan pengabdian kepada masyarakat ini adalah mix method dari mulai sosialisasi, wawancara, penyuluhan, pelatihan dan 
diskusi interaktif serta diiringi Fun Games yang berkaitan dengan materi yang disampaikan.

Kegiatan lebih rinci tertuang di dalam tabel di bawah ini:

Tabel 1.

\section{Rincian Metode dan Capaian}

\begin{tabular}{|c|c|c|}
\hline Metode & Materi & Capaian \\
\hline Cer & $\begin{array}{l}\text { Peran santri } \\
\text { di era digital } \\
\text { dan } \\
\text { tantangan } \\
\text { dakwah di } \\
\text { era digital }\end{array}$ & $\begin{array}{l}\text { Peserta mampu } \\
\text { mempersiapkan } \\
\text { diri sebagai } \\
\text { kader dakwah } \\
\text { dalam } \\
\text { menghadapi } \\
\text { tantangan } \\
\text { dakwah di era } \\
\text { digital }\end{array}$ \\
\hline Disk & $\begin{array}{l}\text { Peran santri } \\
\text { dalam } \\
\text { menghadapi } \\
\text { tantangan } \\
\text { dakwah di } \\
\text { era digital }\end{array}$ & $\begin{array}{l}\text { Membuka } \\
\text { wawasan } \\
\text { pengetahuan dan } \\
\text { menggali } \\
\text { pengetahuan } \\
\text { dakwah peserta } \\
\text { melalui diskusi } \\
\text { interaktif }\end{array}$ \\
\hline $\begin{array}{l}\text { Fun } \\
\text { Games }\end{array}$ & $\begin{array}{l}\text { Logika } \\
\text { berpikir } \\
\text { berbasis IT }\end{array}$ & $\begin{array}{l}\text { Peserta mampu } \\
\text { merefresh diri } \\
\text { dalam kegiatan }\end{array}$ \\
\hline
\end{tabular}

Sumber: Dokumentasi Penulis, 2019

\section{HASIL DAN PEMBAHASAN}

Era digital atau media baru adalah keadaan dimana manusia menggunakan media baru dalam berkomunikasi, keadaan dimana pergeseran alat komunikasi dari manual ke automatic, dari rumit menjadi mudah, dari waktu yang lama menjadi sangat cepat.

Karakteristik Media baru memiliki karakteristik dapat dimanipulasi, bersifat jaringan atau internet. selain internet seperti media cetak, televisi, majalah, Koran dan lain-lain bukanlah termasuk dalam kategori media baru.

Media massa Beralih ke media baru (internet) karena ada pergeseran budaya dalam sebuah penyampaian informasi. Kemampuan media baru (Internet) yang lebih memudahkan masyarakat dalam menerima informasi lebih cepat dalam hal ini internet yang membuat media massa berbondong-bondong pindah haluan.

Modernisasi yang terjadi di masyarakat membawa dampak terhadap pengaruh orang tua atas pilihan pekerjaan anak. Pada masyarakat tradisional pengaruh orang tua terhadap pilihan-pilihan pekerjaan anak sangat besar dan lagi pilihan pekerjaan anak masih terbatas. Pada masyarakat modern pilihan orang tua terhadap pekerjaan anak cenderung rendah, hal ini karena anak 
memiliki berbagai pilihan pekerjaan dan tingkat pendidikan tinggi. Tetapi pada masyarakat yang sangat modern kembali pengaruh orang tua terhadap pilihan pekerjaan anak besar atau kuat, karena saingan untuk mendapatkan pekerjaaan semakin banyak.

Banyak orang yang justru terjebak dalam penerimaan kemunculan digital yang menjadikan manusia menjadi tidak manusiawi seperti menurun bahkan hilangnya etika, moral, dan budaya. Contoh sederhana; saat dosen tengah menjelaskan materi banyak mahasiswa bermain dengan gadgetnya; instagram, facebook, twitter dan lain-lain. Inilah sebuah etika tidak lagi menjadi prioritas.

Mengacu pada nilai-nilai etika, moral dan budaya inilah maka tantangan terbesar adalah bagaimana individu-individu dapat siap dalam menerima era budaya digital ini.

Menurut Setiawan (2017) Era digital telah membawa berbagai perubahan yang baik sebagai dampak positif yang bisa gunakan sebaik-baiknya. Namun dalam waktu yang bersamaan, era digital juga membawa banyak dampak negatif, sehingga menjadi tantangan baru dalam kehidupan manusia di era digital ini. Tantangan pada era digital telah pula masuk ke dalam berbagai bidang seperti politik, ekonomi, sosial budaya, pertahanan, keamanan, dan teknologi.

Dalam teori sosiologi gerakan sosial terbagi pada dua model yaitu action oriented dan structure oriented, jika gerakan pertama lebih kepada muncul dari bawah yang disebabkan pada ketidakpuasan, keprihatinan dan frustasi masyarakat, maka untuk model gerakan sosial kedua ialah lebih menekankan pada konteks struktural yang memfasilitasi atau menghambat munculnya gerakan sosial masyarakat. Gerakan sosial masyarakat akan berkembang jika kondisi, situasi, dan keadaan kondusif.

Teori dependensi media dibangun berdasarkan gagasan bahwa semakin orang tergantung pada media massa untuk memenuhi kebutuhannya maka peran media massa dalam hidup seseorang dipandang menjadi sangat penting dan karena itu media massa akan memiliki pengaruh yang besar terhadap orang tersebut. Saat ini yaitu gadget menjadi "sandaran" hidup masyarakat, di era digital dari berbagai sisi masyarakat telah terkepung oleh media dalam berkomunikasi tidak terkecuali dakwah.

Pesantren menurut Dhofier (dalam Damopolii. 2011: 156) secara umum pesantren diartikan sebagai tempat tinggal para santri. Kemudian secara etimologis kata pesantren diduga berasal dari kata santri 
yang ditambah awalan pe- di depan dan akhiran -an yang berarti tempat tinggal santri. Sedangkan C.C Berg (dalam Damopolii. 2011 : 56) berpendapat bahwa pesantren berasal dari istilah shastri yang dalam bahasa India berarti orang yang tahu buku-buku suci agama Hindu, atau seorang sarjana ahli kitab suci agama Hindu.

Pondok Pesantren sebagai lembaga pendidikan dijadikan sebagai pengembangan konsep-konsep agama Islam dalam rangka memenuhi kebutuhan emosional dan spiritual warga negara. Jumlah pondok pesantren di Indonesia pada tahun 2016 terdapat 28,194 pesantren yang tersebar baik di wilayah kota maupun pedesaan dengan 4,290,626 santri (Republika, 2017). Sedangkan di bulan Agustus 2019 data pondok pesantren berjumlah 25.938 buah dan jumlah santri 3.962.700 (Pangkalan Data Pondok Pesantren, Agustus 2019).

Selain itu potensi pengkaderan ulama di pesantren Indonesia masih sangat kecil peminatnya, padahal pengkaderan ulama sangat dibutuh dalam penyebaran ajaran Islam di Indonesia. Menurut Suwito (dalam Asy`ari, 2011) mengatakan Al-Quran sangat peduli dan memerintahkan manusia untuk belajar dari masa ke masa baik pada masa klasik sampai masa modern sekarang ini Q.S. Al-Alaq mengandung pengertian bahwa

manusia wajib pandai membaca, justru itu wajiblah ia belajar dan kemampuan membaca itu diperoleh dari belajar.

Dakwah yang fleksibel dan mengikuti zaman akan senantiasa diterima di tengahtengah masyarakat, hal ini telah diisyaratkan Allah dalam Q.S. An-Nahl: 125. Penggunaan teknologi menjadi hal yang harus dibiasakan oleh santri dalam dakwah Islam, teknologi dapat menjadi sarana penyebaran dakwah yang efektif, efisien dan menyenangkan sehingga dapat dengan mudah masuk ke tengah-tengah masyarakat baik yang ada di pedesaan maupun di perkotaan.

Hasil yang didapat dari kegiatan pengabdian kepada masyarakat berupa penyuluhan dan diskusi serta fun games menunjukan bahwa kenyataan di lapangan para santri di pondok pesantren Hidayatul Mubtadi`ien dan Nurul Ummah Putri Kotagede Yogyakarta sudah siap dalam menghadapi tantangan di era digital hal ini dibuktikan adanya website yang mereka kelola dan sangat berpengaruh dengan materi yang disampaikan oleh pemateri, selain itu pondok pesantren dilengkapi dengan sarana dan prasarana ruang digital yang dapat mendukung para santri untuk mengembangkan dakwah Islam secara digital. 
Berikut kegiatan pengabdian kepada masyarakat di Pondok Pesantren Hidayatul Mubtadi ien dan Nurul Ummah.

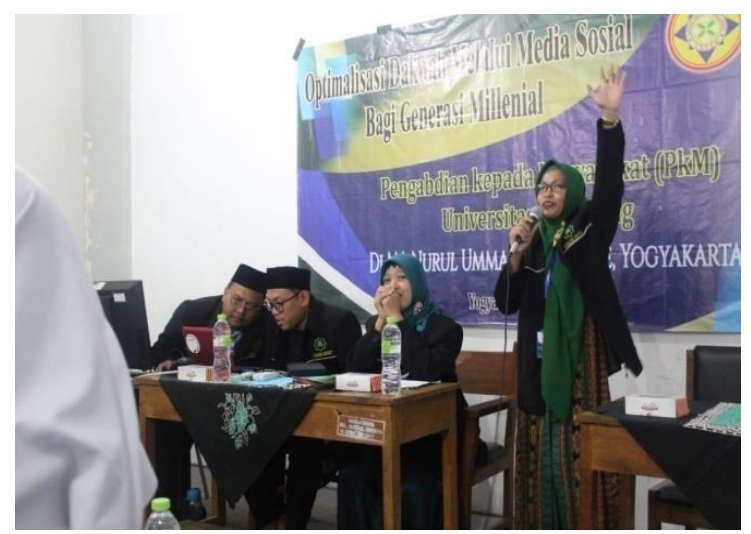

Gambar 1. Narasumber Menyampaikan Materi Kepada Santri

Sumber: dokumentasi penulis, 2019

Berdasarkan gambar 1, narasumber menyampaikan materi terkait dengan konsep dakwah dalam era digital. Dalam pemaparan materi, para santri dapat memahami dengan baik tantangan ke depan bagi para santri dalam menyebarkan ajaran Islam dengan cara beradaptasi dengan perubahan zaman terutama dalam menyampaikan dakwah melalui penggunaan media sosial seperti Fcebook, Twiter, Instagram, Youtube, dan sebagainya.

Jika para santri dapat memanfaatkan secara positif penggunaan teknologi dalam menyebarkan dakwah Islam sangatlah baik untuk dilakukan. Namun ada hal-hal penting yang mereka harus perhatikan dalam melakukan dakwah di media sosial yang

tetap harus sesuai dengan syariat Islam. Para santri juga harus bijaksana dalam menggunakan media sosial agar dampak negatif yang timbul dari penggunaan media sosial perlu dihindari, misalnya keberadaan berita hoax, cyber bullying, konten yang mengandung pornografi, dan sebagainya.

Manfaat dakwah menggunakan internet sangat banyak terutama dakwah menggunakan media sosial semakin terasa manfaatnya bagi generasi muda dengan memberikan materi dakwah dalam keseharian para remaja, dan memberikan solusi-solusi dari berbagai permasalahan yang dihadapi para remaja (Rubawati, 2018).

Kegiatan pengabdian masyarakat selanjutnya diisi dengan pemberian games berbasis teknologi kepada para santri.

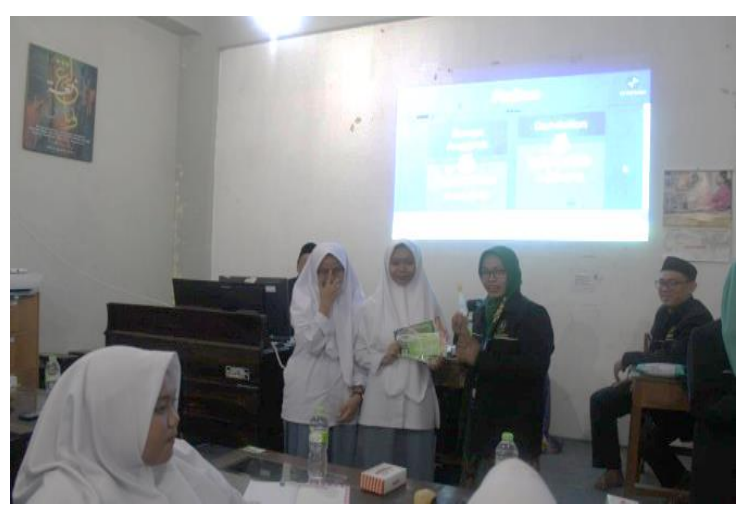

Gambar 2. Kegiatan Fun Games

Sumber: dokumentasi penulis, 2019 
Gambar 2. menggambarkan kegiatan Fun Games terkait dengan materi dengan menggunakan aplikasi Kahoot.it. Dalam kegiatan ini, dapat terlihat antuasias dari para santri yang sangat tinggi dalam mengikuti berbagai kegiatan yang dilakukan selama pengabdian kepada masyarakat.

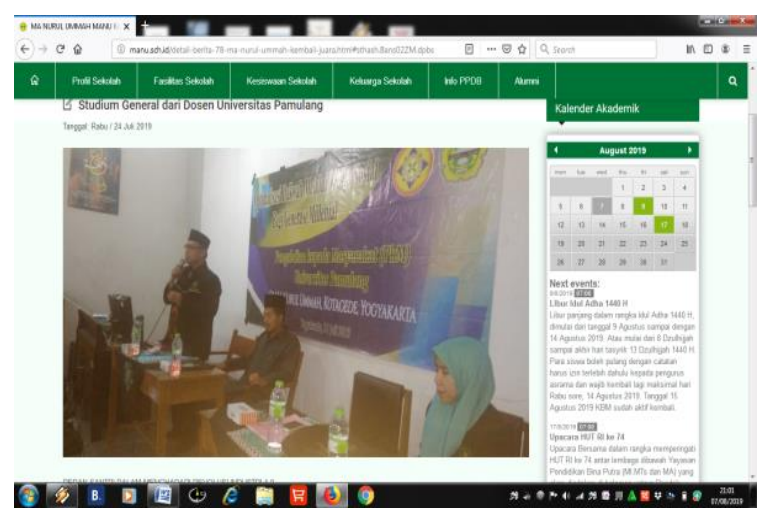

Gambar 3. Website Madrasah Aliyah Nurul Ummah

Sumber: http://manu.sch.id

Gambar 3 menunjukkan bahwa kegiatan pengabdian masyarakat yang dilakukan oleh dosen Universitas Pamulang dimuat di situs resmi Madrasah Aliyah Nurul Ummah Yogyakarta, sehingga diharapkan keberadaan Universitas Pamulang dapat dikenal masyarakat luas dan sebagai kontribusi nyata keberadaan Universitas Pamulang di tengah masyarakat.

\section{KESIMPULAN}

Pondok pesntren Hidayatul Mubtadi ien dan Nurul Ummah bertempat di Madrasah Aliyah Nurul Ummah dengan peserta santri dari kedua pondok pesnatren tersebut. Letak strategis kedua pondok pesantren tersebut yang menjadi salah satu pertimbangan pelaksana untuk melaksanakan kegiatan pengabdian masyarakat.

Masalah yang sangat urgen yaitu banyaknya tantangan dakwah di era digital menjadi latar belakang masalah kegiatan dilaksanakan. Kesiapan pondok pesantren Hidayatul Mubtadi ien dan Nurul Ummah Puteri dalam menghadapi tantangan dakwah di era digital.

Sebagai penyempurna baiknya kegiatan pengabdian kepada masyarakat ini tetap diadakan dengan siat berkelanjutan, hal ini dilakukan untuk menjaga konsistensi dan asas manfaat untuk semua lembaga baik Universitas Pamulang maupun Pondok Pesantren Hidayatul Mubtadi ien dan Nurul Ummah Putri.

\section{UCAPAN TERIMAKASIH}

Kegiatan pengabdian kepada masyarakat ini terlaksana atas bantuan dari beberapa pihak, maka dalam kesempatan ini kami mengucapkan terima kasih kepada Bapak ketua Yayasan Sasmita Jaya Group 
Bapak H. Dr (HC). Darsono yang telah memberikansupportdalam setiap kegiatan yang di laksanakan oleh para dosen, Bapak Rektor dan jajarannya, Dekan Fakultas Ekonomi, Kaprodi Akuntansi S1, Ketua Kordinator LKK Universitas Pamulang dan tentunya Pihak Pondok Pesantren Hidayatul Mubtadi ien dan Nurul Ummah serta Kepala Madrasah Aliyah Nurul Ummah yang telah dengan sangat antusias menerima kami dan jamuannya yang luar biasa.

\section{REFERENSI}

Asy`ari, M. (2011). Konsep Pendidikan Islam: Implementasinya dalam Tradisi Klasik dan Propagasi Modern. Jakarta: Rabbani Press.

Damopolii. M. (2011). Pesantren Modern IMM Pencetak Muslim Modern. Jakarta : PT Raja Grafindo Persada.

Madrasah Aliyah Nurul Ummah. (2019). Stadium General dari Dosen Universitas Pamulang. Diakses pada 1 Agustus 2019, dari http://manu.sch.id/ detail-berita- 78-studium- general-daridosen- universitas-pamulang.html.

Maesaroh, N., \& Achdiani, Y. (2017). Tugas Dan Fungsi Pesantren Di Era Modern. Sosietas, 7(1).

Pangkalan Data Pondok Pesantren. (2019). Statistik Jumlah Pesantren. Diakses pada 1 Agustus 2019, dari htps://ditpdpontren.kemenag.go.id/pdp p.

Republika. (2017). Pertumbuhan Pesantren di Indonesia Dinilai Menakjubkan. Diakses pada 1 Agustus 2019, dari https://www.republika.co.id/berita/duni a-islam/islam nusantara /17/11/30/ p0881k 396- pertumbuhan -pesantrendi- indonesia- dinilai- menakjubkan.

Rubawati, E. (2018). Media Baru: Tantangan dan Peluang Dakwah. Jurnal Studi Komunikasi, 2(1).

Setiawan, W. (2017). Era Digital dan Tantangannya. Seminar Nasional Pendidikan. Diakses dari https://core.ac.uk/download/pdf/87779 963.pdf. 
